Reviu Akuntansi dan Bisnis Indonesia, Vol. 3 No. 2, Hlm: 124-138, Desember 2019

Website: http://journal.umy.ac.id/index.php/rab

\title{
Pengaruh Investment Opportunity Set dan Corporate Governance Terhadap Kualitas Laba (Studi Empiris Pada Perusahaan Manufaktur yang Listing di BEI tahun 2011- 2015)
}

\author{
Fathussalmi *; Yeasy Darmayanti, Popi Fauziati \\ Program Studi Akuntansi Universitas Bung Hatta
}

I N F O A R T I K E L

\section{Kata Kunci:}

Kualitas Laba, Investment Opportunity Set, Corporate

Governance.

Jenis Artikel:

Penelitian Empiris

Correspondence:

fathussalmi95@gmail.com

\author{
A B S T R A K
}

Salah satu indikator dalam menilai kinerja perusahaan adalah informasi laba yang diungkapkan dalam laporan keuangan. Sehingga dibutuhkan informasi laba berkualitas yang menggambarkan kondisi perusahaan dan menjadi acuan berbagai pihak dalam pengambilan keputusan. Namun informasi laba juga sering dijadikan sebagai alat oleh manajemen untuk dimanipulasi agar terlihat baik. Hal ini membuat pihak eksternal kurang percaya dan memperkecil keinginan untuk berinvestasi. Penelitian ini bertujuan untuk membuktikan secara empiris pengaruh Investment Opportunity Set, Kepemilikan Manajerial, Dewan Direksi, Dewan Komisaris Independen, dan Komite Audit terhadap Kualitas Laba. Penelitian ini menggunakan data sekunder berupa laporan keuangan seluruh perusahaan manufaktur yang terdaftar di Bursa Efek Indonesia dari tahun 2011-2015. Untuk mewakili populasi, sampel dipilih dengan menggunakan metode purposive sampling yaitu pengambilan sampel dengan kriteria yang ditentukan oleh peneliti. Sampel yang digunakan dalam penelitian yaitu sebanyak 17 perusahaan dengan total observasi yang diteliti yaitu 85. Hasil penelitian menunjukkan bahwa Investment Opportunity Set, Kepemilikan Manajerial, Dewan Direksi, Dewan Komisaris Independen, dan Komite Audit tidak berpengaruh terhadap Kualitas Laba. Sampel yang digunakan dalam penelitian ini relative kecil. Selain itu dikarenakan hasil adjusted $\mathrm{R}$ square menunjukkan bahwa investment opportunity set dan corporate governance hanya menjelaskan $4 \%$ atas kualitas laba.

(C) 2019 RAB. Published by Universitas Muhammadiyah Yogyakarta

\section{PENDAHULUAN}

Laporan keuangan merupakan salah satu sumber informasi yang sangat penting dalam menggambarkan kondisi perusahaan. Di dalam laporan keuangan, berbagai informasi yang dibutuhkan oleh pihak eksternal maupun internal disajikan, sehingga dapat dijadikan sebagai dasar pengambilan keputusan. Salah satu informasi penting yang dijadikan sebagai patokan dalam pengambilan keputusan adalah laba. Laba memberikan informasi tentang kinerja dari pihak manajemen dalam menjalankan tugasnya. Dalam hal ini, laba yang berkualitaslah yang dapat dijadikan sebagai acuan oleh pihak eksternal maupun pihak internal. Laba dapat dikatakan berkualitas tinggi jika laba yang dilaporkan dapat digunakan oleh pengguna laporan keuangan untuk 
membuat keputusan yang terbaik dan memenuhi karakteristik kualitatif laporan keuangan yaitu relevan dan reliabilitas (Warianto, 2013).

Namun tidak bisa dipungkiri bahwa moral hazard selalu membayangi keinginan manajer untuk memperoleh keuntungan pribadi. Sebagai pihak yang lebih mengetahui kondisi perusahaan dibandingkan pihak lain, terdapat kecenderungan manajer melakukan berbagai aktifitas manajemen laba yang mengakibatkan hilangnya kualitas dari laba yang dilaporkan. Seperti kasus mark-up laba pada perusahaan Toshiba tahun 2015 lalu. Akuntansi perusahaan terbukti menggelembungkan keuntungan perusahaan selama enam tahun terakhir. Tim independen yang ditunjuk oleh Toshiba menyimpulkan perusahaan itu telah menggelembungkan laba mencapai 151,8 miliyar yen atau sekitar Rp. 16 Triliun. Jumlah tersebut mencapai tiga kali lipat estimasi keuntungan yang diprediksi oleh Toshiba. Hal ini menyebabkan mundurnya CEO dan Presiden dari Toshiba itu sendiri (Sumber: Beritasatu.com). Kasus Toshiba diatas adalah salah kondisi yang membuat pihak eksternal seperti investor kurang percaya akan perusahaan dan tidak mau untuk berinvestasi pada saham perusahan. Kesempatan investasi dari para investor ini biasa disebut dengan Investment Opportunity Set (IOS).

Investment Opportunity Set (IOS) merupakan kesempatan yang ada pada perusahaan agar bisa tumbuh dengan baik. IOS dapat dijadikan dasar untuk menentukan pertumbuhan di masa depan (Warianto, 2013). Nilai-nilai dasar yang diputuskan saat ini akan mempengaruhi keputusan investasi di masa yang akan datang. Apabila manajer salah mengambil langkah dalam menentukan keputusan saat ini, maka kesempatan investasi di masa yang akan datang juga ikut terganggu. Beberapa penelitian yang meneliti tentang pengaruh Investment Opportunity Set terhadap Kualitas Laba menemukan bahwa terdapat pengaruh positif dan signifikan IOS terhadap kualitas laba (Paulus, 2012; Puteri, 2012), sementara Adriani (2011) menemukan sebaliknya.

Selain IOS, konflik keagenan juga dapat ditekan dengan menerapkan corporate governance dalam sistem pengendalian dan pengelolaan perusahaan (Puteri, 2012). Konflik keagenan terjadi akibat perbedaan kepentingan antara pihak agen dan prinsipal yang berujung pada tidak berkualitasnya laba karena kegiatan manajemen laba yang dilakukan manajemen.

Corporate Governance sebagai sebuah sistem yang mengatur perusahaan dapat menjadi pengawas manajemen dalam hal mengelola perusahaan sehingga prinsipal yakin bahwa mereka akan mendapatkan return atas dana yang mereka investasikan di perusahaan. Corporate Governance dapat menjadi penghambat bagi manajemen yang ingin melakukan tindakan manajemen laba dan membuat investor menjadi percaya terhadap laba yang diinformasikan oleh manajemen.

Penelitian ini dimotivasi oleh penelitian Adriani (2011) yang meneliti pengaruh investment opportunity set dan mekanisme corporate governance terhadap kualitas laba dan nilai perusahaan. Mekanisme corporate governance yang digunakan dalam penelitian Adriani (2011) yaitu komite audit, komisaris independen, kepemilikan institusional, kepemilikan manajerial serta ukuran kap, ukuran perusahaan, serta leverage sebagai variabel kontrol. Hasil penelitian Adriani (2011) menunjukkan bahwa komisaris independen, kepemilikan institusional, kepemilikan manajerial memiliki pengaruh terhadap kualitas laba. Sedangkan investment opportunity set, proporsi komite audit independen tidak memiliki pengaruh terhadap kualitas laba. Penelitian ini berbeda dengan penelitian sebelumnya, dimana peneliti menambah variabel untuk corporate governance yaitu dewan direksi, serta memperbaharui periode pengamatan yaitu tahun 2011-2015.

\section{TINJAUAN LITERATUR DAN PERUMUSAN HIPOTESIS}

\section{Teori Keagenan}

Teori keagenan dinyatakan pertama kali oleh Jensen and Meckling pada tahun 1976. Jensen and Meckling (1976) menyebut manajer suatu perusahaan sebagai "agen" dan pemegang saham sebagai "prinsipal". Pemegang saham mendelegasikan pengambilan keputusan bisnis kepada manajer yang merupakan agen atau perwakilan dari pemegang saham. Permasalahan yang 
kemudian muncul adalah bahwa agen tidak selalu membuat keputusan-keputusan yang bertujuan untuk memenuhi kepentingan terbaik prinsipal. Hal ini dapat mengakibatkan kecenderungan manajer untuk memfokuskan pada proyek dan investasi yang menghasilkan laba tinggi dalam jangka pendek daripada memaksimalkan kesejahteraan pemegang saham melalui investasi di proyekproyek yang menguntungkan dalam jangka panjang.

Solusi dari masalah Keangenan ini yaitu dengan diterapkannya Corporate Governance. Adanya Corporate Governance didalam perusahaan diharapkan dapat menjadi solusi masalah antara prinsipal dan agen. Corporate Governance juga dapat menjadi alat ataupun cara bagi prinsipal dalam mengawasi dan memonitor kerja para para agen di perusahaan agar mereka melakukan tindakan yang sesuai dengan keinginan dari prinsipal.

\section{Kualitas Laba}

Laba yang berkualitas adalah laba yang dapat mencerminkan kelanjutan laba (sustainable earnings) dimasa depan, yang ditentukan oleh komponen akrual dan kas dan dapat mencerminkan kinerja keuangan perusahaan yang sesungguhnya (Djamaluddin, 2008 dalam Wulansari, 2013). Sejalan dengan itu, Dechows et al. (2010) mendefinisikan kualitas laba sebagai berikut: "Higher quality earnings provide more information about the features of a firms financial performance that are relevant to a specific decision made by a specific decision maker".

Ada tiga hal yang perlu diperhatikan dari definisi tersebut. Yang pertama, kualitas laba tergantung pada informasi yang relevan dalam membuat keputusan. Yang kedua, kualitas jumlah laba yang dilaporkan tergantung pada apakah informasi tersebut menggambarkan kinerja keuangan perusahaan. Yang ketiga yaitu kualitas laba secara bersama-sama ditentukan oleh relevansi dari kinerja yang mendasari keputusan tersebut dan dengan kemampuan sistem akuntansi untuk mengukur kinerja (Dechows et al, 2010).

\section{Investment Opportunity Set}

Investment Opportunity Set dikemukakan pertama kali oleh Myers (1977) yang menguraikan perusahaan sebagai suatu kombinasi antara aktiva riil (assets in place) dan opsi investasi masa depan. Lebih lanjut Adriani (2011) menjelaskan secara umum Investment Opportunity Set (IOS) menggambarkan tentang luasnya kesempatan atau peluang investasi bagi suatu perusahaan, namun sangat tergantung pada pilihan expenditure perusahaan untuk kepentingan dimasa yang akan datang. Apabila suatu perusahaan memiliki nilai IOS yang tinggi, maka hal ini mencerminkan bahwa nilai perusahaan juga tinggi, begitu juga sebaliknya.

Kallapur dan Trombley (2001) membagi proksi dari investment opportunity set kedalam tiga proksi: 1). Berdasarkan harga (price-based proxies) menyatakan bahwa prospek pertumbuhan perusahaan secara parsial dinyatakan dalam harga-harga saham; 2). Berdasarkan investasi (investment-based proxies), dimana proksi ini menyatakan bahwa tingkat tertinggi dari aktivitas investasi berkaitan positif dengan invesment opportunity set pada perusahaan; 3). Berdasar varian (variance measures), dimana proksi ini mengungkapkan bahwa suatu opsi akan menjadi lebih bernilai jika menggunakan variabilitas return yang mendasari peningkatan aktiva.

\section{Corporate Governance}

Menurut Forum for Corporate Governance in Indonesia (FCGI) dalam Muid (2009), definisi Corporate Governance yaitu seperangkat peraturan yang mengatur hubungan antara pemegang saham, pengurus (pengelola) perusahaan, pihak kreditur, pemerintah, karyawan, serta para pemegang kepentingan internal dan eksternal lainnya yang berkaitan dengan hak-hak dan kewajiban mereka atau dengan kata lain suatu sistem yang mengendalikan perusahaan.

Beberapa mekanisme dari corporate governance seperti Kepemilikan Manajerial, Dewan Direksi, Komposisi Dewan Komisaris Independen dan Komite Audit akan digunakan dalam 
penelitian ini sebagai indikator yang membantu menjadi solusi dalam masalah antara prinsipal dan manajer.

Kepemilikan Manajerial

Memiliki direktur independen menjadi hal yang penting untuk efektivitasnya fungsi pengawasan dewan, tingkat kepemilikan saham yang dimiliki oleh manajemen juga dapat mempengaruhi kontrol atas dewan (Hashim dan Devi, 2008). Kepemilikan saham oleh manajemen disebut dengan kepemilikan manajerial. Kepemilikan manajerial yaitu kepemilikan saham oleh manajemen yang secara aktif ikut mengambil keputusan perusahaan (Muid, 2009).

Dewan Direksi

Menurut UU No 40 Tahun 2007, Direksi adalah Organ Perseroan yang berwenang dan bertanggung jawab penuh atas pengurusan Perseroan untuk kepentingan Perseroan, sesuai dengan maksud dan tujuan Perseroan serta mewakili Perseroan, baik di dalam maupun di luar pengadilan sesuai dengan ketentuan anggaran dasar. Dapat disimpulkan bahwa dewan direksi yaitu direksi yang bertugas atau bertanggung jawab mengurus perusahaan.

Dewan Komisaris Independen

Definisi dari Dewan komisaris berdasarkan UU No. 40 Tahun 2007 merupakan organ Perseroan yang bertugas melakukan pengawasan secara umum dan/atau khusus sesuai dengan anggaran dasar serta memberi nasihat kepada direksi. Dewan Komisaris bertanggung jawab melakukan pengawasan atas kebijakan pengurusan, jalannya pengurusan pada umumnya, baik mengenai perusahaan maupun usaha perusahan, dan memberi nasihat kepada Direksi sesuai dengan maksud dan tujuan dari perusahaan.

Komite Audit

Komite Audit merupakan pihak yang menjembatani antara eksternal auditor dan perusahaan sekaligus menjembatani fungsi pengawasan dewan komisaris dengan internal auditor (Indrawati dan Yullianti, 2010). Tugas komite audit meliputi menelaah kebijakan akuntansi yang diterapkan oleh perusahaan, menilai pengendalian internal, menelaah sistem pelaporan eksternal dan kepatuhan terhadap peraturan (Suaryana, 2007).

Pengaruh Investment Opportunity Set Terhadap Kualitas Laba

Menurut Adriani (2011) menemukan bahwa Investment Opportunity Set tidak berpengaruh terhadap kualitas laba. Puteri (2012) menemukan bahwa Invetsment Opportunity Set berpengaruh secara negatif terhadap kualitas laba. Paulus (2012) yang menemukan bahwa terdapat pengaruh positif dan signifikan Investment Opportunity Set terhadap kualitas laba. Wulansari (2013) juga menemukan bahwa Invetsment Opportunity Set tidak mempunyai pengaruh signifikan terhadap kualitas laba. Berbeda dengan penelitian. Warianto (2013) menemukan bahwa Investment Opportunity Set berpengaruh terhadap kualitas laba.

Berdasarkan dari hasil penelitian diatas, maka hipotesis yang dapat diajukan sebagai berikut:

$\boldsymbol{H}_{\boldsymbol{I}} \quad$ : Investment Opportunity Set berpengaruh terhadap Kualitas Laba 
Pengaruh Kepemilikan Manajerial terhadap Kualitas Laba

Dalam penelitiannya Muid (2009) yang menemukan bahwa kepemilikan manajerial secara positif dan signifikan mempengaruhi kualitas laba, sesuai dengan teori yang menyatakan bahwa semakin besar kepemilikan dalam perusahaan maka manajemen akan cenderung untuk berusaha meningkatkan kinerjanya. Adriani (2011) juga menemukan bahwa Kepemilikan Manajerial mempunyai pengaruh terhadap Kualitas Laba. Penelitiannya menunjukkan bahwa kepemilikan saham oleh manajer (komisaris dan direksi) mampu meningkatkan kualitas laba.

Namun, Paulus (2012) menemukan bahwa tidak terdapat pengaruh signifikan kepemilikan manajerial terhadap kualitas laba. Sama hal nya dengan Puteri (2012) juga menemukan bahwa kepemilikan manajerial tidak berpengaruh terhadap kualitas laba. Tohir (2013) menemukan juga bahwa kepemilikan manajerial tidak memiliki pengaruh terhadap kualitas laba.

Berdasarkan hasil penelitian sebelumnya, maka hipotesis yang dapat diajukan yaitu:

\section{$\boldsymbol{H}_{2} \quad$ : Kepemilikan Manajerial berpengaruh terhadap Kualitas Laba}

Pengaruh Dewan Direksi terhadap Kualitas Laba

Hasil penelitian Yushita dkk (2013) menemukan bahwa struktur dewan direksi berpengaruh negatif terhadap kualitas laba. Namun, penelitian dari Oktaviani (2015) juga menemukan bahwa Dewan Direksi berpengaruh signifikan terhadap Kualitas Laba. Rahmah (2015) juga menemukan bahwa proporsi dewan direksi berpengaruh positif signifikan terhadap kualitas laba.

Berdasarkan dari hasil penelitian sebelumnya, maka hipotesis yang dapat diajukan yaitu:

\section{$H_{2 b} \quad$ : Dewan Direksi berpengaruh terhadap Kualitas Laba}

Pengaruh Dewan Komisaris Independen terhadap Kualitas Laba

Penelitian Adriani (2011) menemukan bahwa keberadaan komisaris independen mempunyai pengaruh terhadap kualitas laba. Ia juga menjelaskan bahwa komisaris independen melalui fungsi monitoring atas pelaporan keuangan diharapkan dapat meningkatkan kualitas laba dengan membatasi tindakan manajemen laba yang dilakukan oleh pihak manajemen dalam suatu perusahaan.

Berbeda dengan Puteri (2012) menemukan bahwa komposisi komisaris independen tidak berpengaruh terhadap kualitas laba. Sama dengan penelitian Paulus (2012) menemukan tidak terdapat pengaruh signifikan komisaris independen terhadap kualitas laba.

Berdasarkan hasil penelitian diatas, maka dapat diajukan hipotesis sebagai berikut:

\section{$\boldsymbol{H}_{\boldsymbol{u}_{c}} \quad$ : Dewan Komisaris Independen berpengaruh terhadap Kualitas Laba}

Pengaruh Komite Audit terhadap Kualitas Laba

Berdasarkan hasil Indrawati dan Yulianti (2010) menemukan bahwa komite audit tidak berpengaruh signifikan terhadap kualitas laba. Penelitian Adriani (2011) proporsi komite audit independen tidak mempunyai pengaruh terhadap kualitas laba. Hal ini berarti komite audit independen yang diukur dari persentase jumlah komite audit independen dengan jumlah seluruh komite audit dalam perusahaan belum dapat mengurangi manajemen laba yang dilakukan pihak manajemen dalam suatu perusahaan. Penelitian dari Puteri (2012) menyatakan jumlah rapat komite audit secara positif berpengaruh terhadap kualitas laba. Sama hal nya dengan penelitian. Simamora 
(2014) menemukan bahwa secara individual komite audit memiliki pengaruh signifikan terhadap kualitas laba. berikut:

Berdasarkan hasil penelitian sebelumnya, maka hipotesis yang dapat diajukan sebagai

\section{$\boldsymbol{H}_{s_{d}} \quad$ : Komite Audit berpengaruh terhadap Kualitas Laba}

Kerangka Konseptual

Berdasarkan telaah pustaka, baik teoritis maupun empiris, peneliti menggambarkan kerangka pemikiran sebagai berikut:

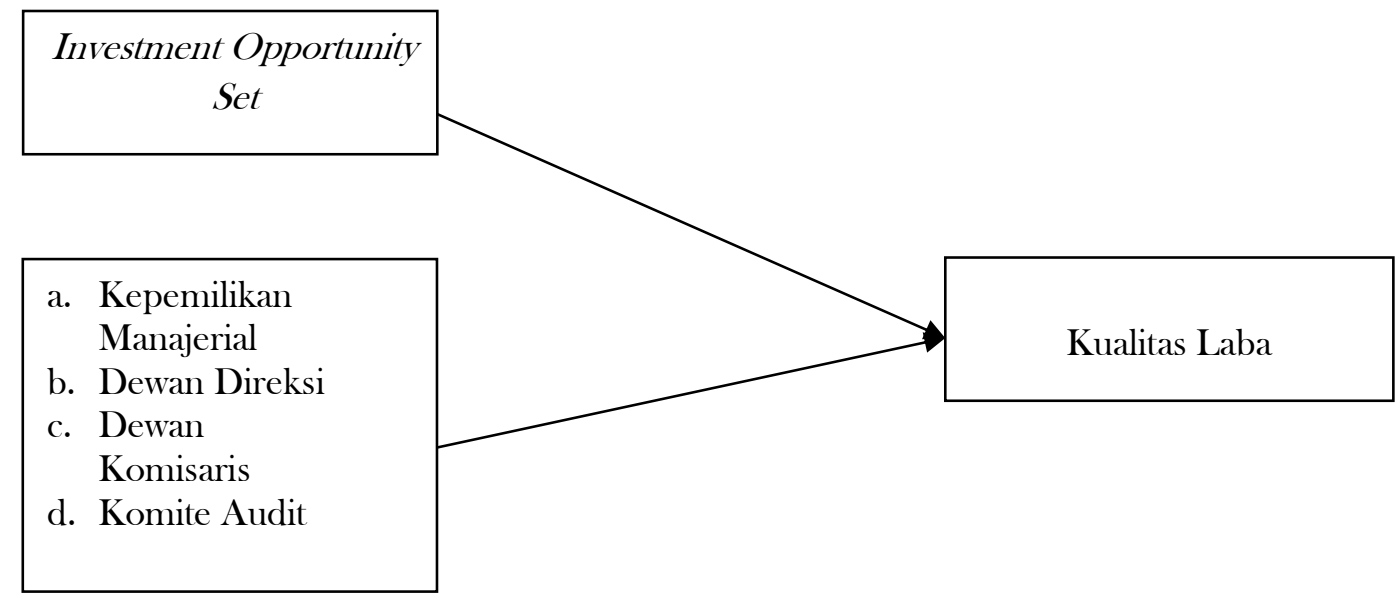

Gambar 1 Kerangka Konseptual

\section{METODE PENELITIAN}

\section{Sumber Data, Populasi, dan Sampel}

Jenis data yang digunakan dalam penelitian yaitu data sekunder. Data yang digunakan berupa laporan keuangan yang telah diaudit. Selain laporan keuangan, data yang digunakan juga annual report untuk melihat corporate governance dengan tahun penelitian yaitu 2011 - 2015. Data dapat diambil dari website resmi Bursa Efek Indonesia yaitu www.idx.co.id. Populasi yang digunakan pada penelitian ini yaitu seluruh perusahaan manufaktur yang terdaftar di Bursa Efek Indonesia dari tahun 2011-2015. Sedangkan sampel penelitian menggunakan metode purposive sampling yaitu pengambilan sampel dengan kriteria yang ditentukan oleh peneliti. Sampel yang digunakan dalam penelitian yaitu sebanyak 17 perusahaan dengan total observasi yang diteliti yaitu 85 .

\section{Definisi Variabel Penelitian dan Pengukurannya}

Variabel Dependen yang digunakan dalam penelitian ini adalah Kualitas Laba, yaitu laba yang dapat mencerminkan kelanjutan laba (sustainable earnings) dimasa depan, yang ditentukan oleh komponen akrual dan kas dan dapat mencerminkan kinerja keuangan perusahaan yang sesungguhnya (Djamaluddin, 2008 dalam Wulansari, 2013). Kualitas laba diukur dengan discretionary accruals (DACC) yang dihitung dengan cara menselisihkan total accruals (TACC) dan nondiscretrionary accruals (NDACC). Menurut Dechow et al. (1995) dalam menghitung DACC, digunakan Modified Jones Model. Berikut adalah rumus dalam menghitung DACC: 
$\mathrm{DACC}_{\mathrm{it}}$

$\mathrm{TACC}_{\mathrm{it}}$

$\mathrm{TACC}_{\mathrm{i} /} / \mathrm{TA}_{\mathrm{i},-1}$

$\mathrm{NDACC}_{\mathrm{it}}$
$=\left(\mathrm{TACC}_{\mathrm{i} /} / \mathrm{TA}_{\mathrm{i}, \mathrm{1}-1}\right)-\mathrm{NADCC}_{\mathrm{it}}$

$=\mathrm{EBXT}_{\mathrm{it}}-\mathrm{OCF}_{\mathrm{it}}$

$=\alpha_{1}\left(1 / \mathrm{TA}_{\mathrm{i}-1-1}\right)+\alpha_{2}\left(\left(\Delta \mathrm{REV}_{\mathrm{it}}-\Delta \mathrm{REC}_{\mathrm{it}}\right) / \mathrm{TA}_{\mathrm{i}-1-1}\right)+\alpha_{3}\left(\mathrm{PPE}_{\mathrm{it}} / \mathrm{TA}_{\mathrm{i},-1}\right)+\varepsilon_{\mathrm{it}} \ldots \ldots . . .(2)$

$=\alpha_{1}\left(1 / \mathrm{TA}_{\mathrm{i}-1-1}\right)+\alpha_{2}\left(\left(\Delta \mathrm{REV}_{\mathrm{it}}-\Delta \mathrm{REC}_{\mathrm{it}}\right) / \mathrm{TA}_{\mathrm{i},-1}\right)+\alpha_{3}\left(\mathrm{PPE}_{\mathrm{i} /} / \mathrm{TA}_{\mathrm{i},-1-1}\right)$

Variabel independen yang digunakan dalam penelitian ini yaitu Investment Opportunity Set dan Corporate Governance. Berikut definisi dan pengukurannya:

Investment Opportunity Set

Merupakan keputusan investasi dalam bentuk kombinasi dari aktiva yang dimiliki (assets in place) dan opsi investasi dimasa yang akan datang, dimana IOS tersebut akan mempengaruhi nilai suatu perusahaan (Pagaulung, 2003 dalam Puteri, 2012). IOS dapat diproksikan dengan Market to Book Value of Equity. Rasio ini merupakan perbandingan antara total nilai saham beredar (outstanding stock's value) dengan keseluruhan ekuitas perusahaan (Yusuf dan Erick, 2005).

Kepemilikan Manajerial

Kepemilikan manajerial adalah jumlah kepemilikan saham oleh pihak manajemen perusahaan terhadap total jumlah saham beredar (Indrawati dan Yulianti, 2010). Variabel ini diproksikan dengan menghitung persentase saham yang dimiliki oleh manajemen dibandingkan dengan total jumlah saham perusahaan yang beredar (Muid, 2009).

\section{Dewan Direksi}

Direksi adalah organ perseroan yang berwenang dan bertanggung jawab penuh atas pengurusan Perseroan (UU No 40 tahun 2007). Dewan direksi diproksikan melalui jumlah dewan direksi yang ada didalam perusahaan (Oktaviani, 2015).

Dewan Komisaris Independen

Komisaris independen diangkat berdasarkan keputusan RUPS dari pihak yang tidak terafiliasi dengan pemegang saham utama, anggota Direksi dan/atau anggota Dewan Komisaris lainnya (UU No.40 Tahun 2007 pasal 120). Variabel ini diproksikan dengan persentase jumlah komisaris independen terhadap jumlah total komisaris yang ada dalam susunan dewan komisaris (Paulus, 2012)

Komite Audit

Komite audit adalah komite yang harus beranggotakan minimal tiga orang independen dan salah satunya memiliki keahlian dalam bidang akuntansi (Indrawati, 2011). Komite audit dapat diproksikan dengan melihat jumlah nominal dari anggota komite audit yang ada dalam perusahaan (Simamora, 2014).

\section{Uji Asumsi Klasik}

Uji Normalitas

Uji normalitas bertujuan untuk menguji apakah dalam model regresi, variabel pengganggu atau residual memiliki distribusi normal (Ghozali, 2013). Untuk menguji normalitas suatu data, dalam penelitian ini digunakan model regresi One-Sample kolmogorov-Smirnov. Dasar pengambilan keputusan dalam uji One-Sample Kolmogorov-Smirnov sebagai berikut (Ghozali, 2013) : 
a. Jika hasil dari Asymp. Sig > 0.05 maka Ha diterima, data berdistribusi normal.

b. Jika hasil dari Asymp. Sig < 0.05 maka Ha ditolak, data tidak berdistribusi normal.

Uji Multikolinearitas

Uji multikolinearitas bertujuan untuk menguji apakah model regresi ditemukan adanya korelasi antar variabel bebas (independent variable). Model regresi yang baik seharusnya tidak terjadi korelasi diantara variabel bebas, karena jika hal tersebut terjadi maka variabel-variabel tersebut tidak ortogonal atau terjadinya kemiripan. Variabel ortogonal adalah variabel bebas yang nilai korelasi antar sesama variabel bebas bernilai nol (Ghozali, 2013). Untuk mendeteksi apakah terjadi problem nultikol dapat melihat nilai tolerance dan variance inflation factor (VIF). Nilai Cutoff yang digunakan adalah nilai tolerance $\leq 0,10$ atau sama dengan nilai VIF $\geq 10$. Apabila hasil analisis menunjukkan nilai tolerance diatas 0,10 dan nilai VIF dibawah 10, maka tidak terjadi multikolinearitas antara variabel didalam variabel model regresi (Ghozali, 2013).

Uji Autokorelasi

Menurut Ghozali (2013) uji autokorelasi bertujuan menguji apakah dalam model regresi linear ada korelasi antara kesalahan pengganggu pada periode t dengan kesalahan pengganggu pada periode t-1 (sebelumnya). Jika terjadi korelasi, maka dinamakan ada problem autokorelasi. Model regresi yang baik adalah regresi yang bebas dari autokorelasi. Salah satu cara untuk mendeteksi gejala autokorelasi yaitu uji Durbin Watson (DW test). Uji Durbin-Watson hanya digunakan untuk autokorelasi tingkat satu (first oreder autocorrelation) dan mensyaratkan adanya intercept (konstanta) dalam model regresi dan tidak ada variabel lag diantara variabel independen. Uji Durbin-Watson memiliki kriteria sebagai berikut jika DW berada -2 dan +2 berarti tidak terjadi autokorelasi (Santoso, 2010).

Uji Heterokedastisitas

Uji heterokedastisitas bertujuan untuk menguji apakah dalam model regresi terjadi ketidaksamaan variance dari residual satu pengamatan ke pengamatan yang lain. Jika variance dari residual satu pengamatan ke pengamatan lain tetap, maka disebut homokedastisitas dan jika berbeda disebut heterokedastisitas. Model regresi yang baik yaitu homokesdatisitas atau tidak terjadi heteroskedastisitas (Ghozali, 2013). Uji heteroskedastisitas yang digunakan yaitu uji Glejser, yaitu dengan meregres nilai absolut residual terhadap variabel independen. Apabila nilai probabilitas signifikansinya diatas tingkat kepercayaan 5\%, maka model regresi tidak mengandung adanya heteroskedastisitas (Ghozali, 2013).

Teknik Pengujian Hipotesis

Model regresi linear berganda dalam penelitian ini digunakan untuk menyatakan pengaruh variabel bebas dan variabel terikat menggunakan unstandardized coeficient maupun standardized coefficient (Ghozali, 2013). Metoda analisa yang digunakan dalam penelitian ini adalah regresi berganda. Bentuk persamaan dalam penelitian ini adalah:

Keterangan:

$$
Y=\alpha+\beta_{1} X 1+\beta_{2} X 2+\beta_{3} X 3+\beta_{4} X 4+\beta_{5} X 5+\varepsilon
$$

Y : $\quad$ Kualitas Laba

$\alpha$ : Konstanta

$\beta: \quad$ Koefisien regresi

X1: Investment Opportunity Set

X2: Kepemilikan Manajerial 


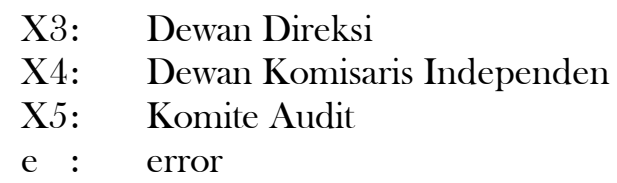

Koefisien Determinasi $\left(\mathrm{R}_{2}\right)$

Koefisien determinasi ( $R_{2}$ ) pada intinya mengukur seberapa jauh kemampuan model dalam menerangkan variabel-variabel dependen. Nilai koefisien determinasi adalah antara nol dan satu. Nilai $\mathbf{R}_{2}$ yang kecil berarti kemampuan variabel-variabel independen dalam menjelaskan variasi variabel dependen amat terbatas. Nilai yang mendekati satu berarti variabel-variabel independen memberikan hampir semua informasi yang dibutuhkan untuk memprediksi variasi variabel dependen (Ghozali, 2013).

\section{Uji Signifikan Simultan (Uji Statistik F)}

Uji statistik $\mathrm{F}$ pada dasarnya menunjukkan apakah semua variabel independen atau bebas yang dimasukan dalam model mempunyai pengaruh secara bersama-sama terhadap variabel dependen/terikat (Ghozali, 2013).

Pengujian hipotesis menggunakan uji signifikan simultan (F-test) dengan kriteria pengambilan keputusan sebagai berikut (Ghozali,2013):

a. Apabila nilai $\mathbf{F}$ hitung $>\mathbf{F}$ tabel atau profitabilitas < nilai signifikan (sig $\leq 0,05$ ) maka hipotesis diterima, artinya terdapat pengeruh yang signifikan antara semua variabel independen terhadap variabel dependen.

b. Apabila nilai $\mathbf{F}$ hitung $<\mathrm{F}$ tabel atau profitabilitas $>$ nilai signifikan ( $\operatorname{sig} \geq 0,05$ ) maka hipotesis ditolak, artinya variabel independen tersebut tidak berpengaruh terhadap variabel dependen.

3. Uji Signifikan Parameter Individual (Uji Statistik t)

Uji statistik $\mathrm{t}$ pada dasarnya menunjukkan seberapa jauh pengaruh satu variabel penjelas/independen secara individual dalam menerangkan variasi variabel dependen. Hipotesis nol (H0) yang hendak diuji adalah apakah suatu parameter (bi) sama dengan nol, atau $\mathrm{H} 0: \mathrm{bi}=0$ artinya adalah suatu variabel independen bukan merupakan penjelas yang signifikan terhadap variabel dependen. Hipotesis alternatifnya $(\mathrm{Ha})$ parameter suatu variabel tidak sama dengan nol, atau $\mathrm{Ha}: \mathrm{bi} \neq 0$ artinya, variabel tersebut merupakan penjelas yang signifikan terhadap variabel dependen (Ghozali, 2013).

\section{HASIL DAN PEMBAHASAN}

Prosedur Pemilihan Sampel

Sampel diperoleh menggunakan metode purposive sampling, sehingga diperoleh 17 perusahaan manufaktur selama 5 periode yaitu 2011 - 2015. Berikut tahapan seleksi pemilihan sampel sesuai dengan kriteria yang telah ditetapkan akan ditampilkan dalam Tabel 1. 
Tabel 1 Tahapan Seleksi Pemilihan Sampel sesuai Kriteria

\begin{tabular}{lc}
\hline \multicolumn{1}{c}{ Kriteria Sampel } & Jumlah Sampel \\
\hline Jumlah perusahaan manufaktur yang terdaftar di BEI sampai tahun 2015 & 146 \\
Jumlah perusahaan manufaktur yang tidak listing di BEI secara terus menerus dari tahun & $(26)$ \\
$2011-2015$ & $(31)$ \\
Jumlah perusahaan yang tidak menyediakan laporan tahunan dan laporan keuangan & \\
periode 2011-2015 & $(6)$ \\
Jumlah perusahaan yang tidak menggunakan mata uang Rupiah & $(66)$ \\
Jumah perusahaan yang mengalami rugi sebelum pajak dan tidak memiliki kelengkapan & 17 \\
lainnya & 85 \\
Jumlah sampel dalam penelitian & \\
Jumlah total obesrvasi dalam penelitian & \\
\hline
\end{tabular}

Sumber: data sekunder yang diolah 2017

Statistik Deskriptif

Statistik deskriptif merupakan proses transformasi data penelitian dalam bentuk tabulasi yang menyajikan ringkasan penyusunan yang dilihat dari nilai rata-rata (mean), standar deviasi, varians, maksimum, dan minimum (Ghozali, 2013). Tabel 2 berikut akan menampilkan hasil perhitungan analisis deskriptif dari penelitian ini:

Tabel 2 Statistik Deskriptif

\begin{tabular}{cccccc}
\hline & N & Minimum & Maksimum & Mean & Std. Deviasi \\
\hline KL & 85 & $-3,13$ & 1,45 & 0,0293 & 0,66663 \\
IOS & 85 & 0,12 & 10,21 & 2,4487 & 2,02387 \\
KM & 85 & 0,00 & 0,26 & 0,0583 & 0,08123 \\
DD & 85 & 3,00 & 15,00 & 5,5529 & 3,23488 \\
DKI & 85 & 0,25 & 0,75 & 0,3765 & 0,08823 \\
KA & 85 & 3,00 & 5,00 & 3,1765 & 0,41336 \\
Valid N & 85 & & & & \\
\hline
\end{tabular}

Sumber: Data Olah SPSS tahun 2017

\section{Hasil Uji Asusmsi Klasik}

Uji Normalitas

Uji normalitas bertujuan untuk menguji apakah dalam model regresi, variabel penganggu atau residual memiliki distribusi normal (Ghozali, 2013). Uji yang digunakan yaitu One-Sample kolmogorov-Smirnov dengan dasar pengambilan keputusan jika nilai signifikansi >0,05 maka dapat dikatakan jika data tersebut berdistribusi normal.

Tabel 3 One Sample Kolmogrov Smirnov Test

\begin{tabular}{cccc}
\hline $\begin{array}{c}\text { Unstandardized } \\
\text { Residual }\end{array}$ & Asymp. Sig. (2-tailed) & Alpha & Kesimpulan \\
\hline $\begin{array}{c}\text { KL, IOS, KM, DD, } \\
\text { DKI, DD }\end{array}$ & 0,309 & 0,05 & Normal \\
\hline
\end{tabular}

Sumber: data olah SPSS tahun 2017

Dari hasil data tersebut dapat dilihat bahwa nilai signifikansi dari data yaitu 0,309 dan memenuhi kriteria dari pengambilan keputusan >0,05 sehingga data menjadi berdistribusi normal.

Uji Multikolinearitas

Uji multikolinearitas bertujuan untuk menguji apakah model regresi ditemukan adanya korelasi antar variabel bebas (independent variable). Untuk mendeteksi apakah terjadi problem 
multikol dapat melihat nilai tolerance dan variance inflation factor (VIF). Nilai Cutoff yang digunakan adalah nilai tolerance $\leq 0,10$ atau sama dengan nilai VIF $\geq 10$ (Ghozali, 2013). Berikut ini merupakan hasil dari uji multikolinearitas dari penelitian ini:

Tabel 4 Hasil Uji Multikolinearitas

\begin{tabular}{cccc}
\hline $\begin{array}{c}\text { Variabel } \\
\text { Independen }\end{array}$ & \multicolumn{2}{c}{ Collinearity Statistics } & \multirow{2}{*}{ Keterangan } \\
\hline TOS & 0,929 & VIF & Tidak Terjadi Multikolinearitas \\
KM & 0,769 & 1,077 & Tidak Terjadi Multikolinearitas \\
DD & 0,452 & 2,211 & Tidak Terjadi Multikolinearitas \\
DKI & 0,681 & 1,467 & Tidak Terjadi Multikolinearitas \\
KA & 0,692 & 1,445 & Tidak Terjadi Multikolinearitas \\
\hline
\end{tabular}

Sumber: Data Olah SPSS tahun 2017

\section{Uji Autokorelasi}

Uji autokorelasi merupakan pengujian asumsi dalam regresi dimana variabel dependen tidak berkorelasi dengan dirinya sendiri. Dalam artian nilai dari variabel dependen tidak berhubungan dengan nilai variabel itu sendiri, baik nilai periode sebelumnya atau nilai periode sesudahnya. Untuk mendeteksi terjadi atau tidak terjadinya autokorelasi dapat dilihat dari nilai Durbin-Watson (D-W). autokorelasi tidak terjadi jika nila D-W berada diantara -2 sampai 2 (Santoso, 2010). Berikut merupakan hasil uji autokorelasi penelitian ini:

Tabel 5 Hasil Uji Autokorelasi

\begin{tabular}{cccc}
\hline Variabel Independen & Durbin - Watson & Cut - off & Kesimpulan \\
\hline $\begin{array}{c}\text { IOS, KM, DD, DKI, } \\
\text { KA }\end{array}$ & 1,693 & -2 sampai 2 & $\begin{array}{l}\text { Tidak terjadi } \\
\text { autokorelasi }\end{array}$ \\
\hline
\end{tabular}

Sumber: Data olah SPSS tahun 2017

\section{Uji Heterokedastisitas}

Uji heterokedastisitas bertujuan untuk menguji apakah dalam model regresi terjadi ketidaksamaan variance dari residual satu pengamatan ke pengamatan yang lain. Model regresi yang baik yaitu homokesdatisitas atau tidak terjadi heteroskedastisitas (Ghozali, 2013). Pengambilan keputusan apabila nilai probabilitas signifikansinya diatas tingkat kepercayaan 5\% atau >0,05. Berikut merupakan hasil dari uji heteroskedastisitas:

Tabel 6 Hasil Uji Heteroskedastisitas

\begin{tabular}{cccc}
\hline Variabel & Sig. & Cut-off & Keterangan \\
\hline IOS & 0,259 & 0,05 & Tidak terjadi heteroskedastisitas \\
KM & 0,450 & 0,05 & Tidak terjadi heteroskedastisitas \\
DD & 0,290 & 0,05 & Tidak terjadi heteroskedastisitas \\
DKI & 0,854 & 0,05 & Tidak terjadi heteroskedastisitas \\
KA & 0,540 & 0,05 & Tidak terjadi heteroskedastisitas \\
\hline
\end{tabular}

Sumber: Data olah SPSS tahun 2017

\section{Hasil Uji Hipotesis}

Setelah semua variabel penelitian yang digunakan terbebas dari gejala asumsi klasik, maka tahapan selanjutnya yaitu pengujian statistik. Berdasarkan hasil pengujian statistik yang dilakukan maka diperoleh hasil seperti pada tabel 7 berikut ini: 
Tabel 7 Hasil Uji Hipotesis

\begin{tabular}{cccccc}
\hline Model & $\boldsymbol{\beta}$ & $\mathbf{t}$ & $\mathbf{S i g}$ & $\boldsymbol{\alpha}$ & Kesimpulan \\
\hline (Constant) & 0,687 & 0,945 & 0,348 & 0,05 & \\
IOS & $-0,037$ & $-1,008$ & 0,317 & 0,05 & Ditolak \\
KM & 0,385 & 0,384 & 0,702 & 0,05 & Ditolak \\
DD & 0,003 & 0,088 & 0,930 & 0,05 & Ditolak \\
DKI & 1,756 & 1,794 & 0,077 & 0,05 & Ditolak \\
KA & $-0,399$ & $-1,925$ & 0,058 & 0,05 & Ditolak \\
$\mathbf{R}^{2} \quad: 0,040$ & & & & & \\
F hitung $: 1,695$ & sig : 0,146 & & & \\
\hline
\end{tabular}

Sumber: Data olah SPSS tahun 2017

Dari tabel 6 maka persamaan regresinya adalah sebagai berikut:

$$
\mathrm{Y}=0,687-0,037 \mathrm{IOS}+0,385 \mathrm{KM}+0,003 \mathrm{DD}+1,756 \mathrm{DKI}-0,399 \mathrm{KA}
$$

Nilai $\mathbf{R}^{2}$ pada tabel 6 menunjukkan bahwa nilai koefisien Adjusted R Square adalah 0,040, hal ini berarti bahwa $4 \%$ variabel kualitas laba dapat dijelaskan oleh variabel investment opportunity set dan corporate governance, sedangkan sisanya $(100 \%-4 \%=96 \%)$ dijelaskan oleh faktor-faktor lain.

Dari tabel 6 diatas dapat diketahui nilai $\mathrm{F}$ hitung penelitian ini sebesar 1,695 dengan probabilitas 0,146 . Hal ini menunjukkan bahwa nilai probabilitas lebih tinggi dari nilai signifikansi yang ditetapkan yaitu 0,05 . Hasil ini berarti bahwa model regresi ini tidak dapat digunakan untuk memprediksi kualitas laba. Dapat disimpulkan bahwa variabel independen investment opportunity set dan corporate governance secara bersama-sama tidak berpengaruh terhadap kualitas laba.

\section{Pengaruh IOS terhadap Kualitas Laba}

Berdasarkan hasil uji penelitian untuk variabel investment opportunity set terhadap kualitas laba didapat nilai koefisien regresi sebesar -0,037, nilai t hitung sebesar 0,-1,008 serta nilai signifikan sebesar 0,317 dimana lebih besar dari nilai $\alpha(0,05)$. Maka dapat disimpulkan hasil penelitian ini menunjukkan bahwa tidak terdapat pengaruh antara investment opportunity set terhadap kualitas laba, sehingga hipotesis yang menyatakan bahwa investment opportunity set berpengaruh terhadap kualitas laba tidak dapat diterima.

Penyebab tidak diterimanya hipotesis dikarenakan investment opportunity set bukan menjadi pusat perhatian dari para investor. Hal ini disebabkan para investor tidak terlalu melihat kepada nilai investment opportunity set perusahaan, melainkan mereka lebih melihat kepada bagaimana angka dari laba perusahaan itu sendiri. Hal ini dikarenakan pada investment opportunity set mengukur dengan menggunakan bagaimana peredaran saham juga nilai ekuitas suatu perusahaan, yang dimana ini tidak terlalu dijadikan sebagai pedoman investor bila mereka ingin berinvestasi dari suatu perusahaan.

\section{Pengaruh Corporate Governance terhadap Kualitas Laba}

Kepemilikan Manajerial dan Kualitas Laba

Berdasarkan hasil pengujian variabel kepemilikan manajerial terhadap kualitas laba didapat nilai koefisien regresi sebesar 0,385 , nilai t hitung sebesar 0,384 serta nilai signifikan sebesar 0,702 dimana lebih tinggi dari $\alpha(0,05)$. Maka dapat disimpulkan hasil penelitian ini menunjukkan bahwa kepemilikan manajerial tidak berpengaruh terhadap kualitas laba, sehingga hipotesis yang menyatakan bahwa kepemilikan manajerial berpengaruh terhadap kualitas laba tidak dapat diterima. 
Hasil penelitian ini tidak sejalan dengan penelitian Indrawati dan Lilla (2010), Paulus (2012), Puteri (2012), Yushita (2013). Namun penelitian ini sejalan dengan Adriani (2011) yang juga menyatakan bahwa kepemilikan manajerial berpengaruh terhadap kualitas laba.

\section{Dewan Direksi dan Kualitas Laba}

Berdasarkan hasil uji penelitian untuk variabel dewan direksi terhadap kualitas laba didapat nilai koefisien regresi sebesar 0,003, nilai t hitung sebesar 0,088 serta nilai signifikan sebesar 0,930 dimana lebih besar dari $\alpha(0,05)$. Maka dapat disimpulkan hasil penelitian ini menunjukkan bahwa dewan direksi tidak berpengaruh terhadap kualitas laba. sehingga hipotesis yang menyatakan bahwa dewan direksi berpengaruh terhadap kualitas laba tidak dapat diterima.

Penelitian ini tidak sejalan dengan penelitian Yushita (2013) yang menemukan bahwa peningkatan struktur dewan direksi dalam suatu perusahaan akan menurunkan kualitas laba perusahaan. Oktaviani (2015) menemukan bahwa dewan direksi berpengaruh terhadap kualitas laba. Rahmah (2015) juga menyebutkan bahwa dewan direksi bepengaruh positif terhadap kualitas laba, sehingga semakin kecil nilai independensi dewan direksi, maka nilai kualitas laba perusahaanakan semakin kecil pula. Begitupula jika nilai independensi dewan direksi semakin tinggi, makas emakin tinggi pula pengaruh signifikannya terhadap kualitas laba.

Dewan Komisaris dan Kualitas Laba

Berdasarkan hasil uji penelitian untuk variabel dewan komisaris independen terhadap kualitas laba didapat nilai koefisien regresi sebesar 1,756, nilai t hitung sebesar 1,794 serta nilai signifikan sebesar 0,077 dimana lebih besar dari $\alpha(0,05)$. Maka dapat disimpulkan hasil penelitian ini menunjukkan bahwa dewan komisaris independen tidak berpengaruh terhadap kualitas laba. sehingga hipotesis yang menyatakan bahwa dewan komisaris independen berpengaruh terhadap kualitas laba tidak dapat diterima.

Penelitian ini tidak sejalan dengan penelitian Adriani (2011), Muid (2009), Tohir (2013). Penelitian ini sejalan dengan Paulus (2012) yang menyatakan bahwa dewan komisaris independen tidak berpengaruh terhadap kualitas laba.

Komite Audit dan Kualitas Laba

Berdasarkan hasil uji penelitian untuk variabel komite audit terhadap kualitas laba didapat nilai koefisien regresi sebesar -0,399, nilai t hitung sebesar -1,925 serta nilai signifikan sebesar 0,058 dimana lebih besar dari $\alpha(0,05)$. Maka dapat disimpulkan hasil penelitian ini menunjukkan bahwa komite audit tidak berpengaruh terhadap kualitas laba, sehingga hipotesis yang menyatakan bahwa komite audit berpengaruh terhadap kualitas laba tidak dapat diterima.

Penelitian ini tidak sejalan dengan Muid (2009), Indrawati (2011), Puteri (2012) dan Simamora (2014). Penelitian ini sejalan dengan penelitian Indrawati dan Yulianti (2010) yang menyatakan bahwa komite audit tidak berpengaruh terhadap kualitas laba.

\section{KESIMPULAN}

Penelitian ini bertujuan untuk melihat pengaruh investment opportunity set dan corporate governance terhadap kualitas laba pada perusahaan manufaktur yang terdaftar di BEI tahun 20112015 dengan jumlah sampel 17 perusahaan dan total sampel dalam penelitian 85. Berdasarkan hasil penelitian dan pengujian hipotesis yang telah diajukan, dapat disimpulkan bahwa Investment opportunity set, kepemilikan manajerial, dewan direksi, dewan komisaris independen, dan komite audit tidak memiliki pengaruh terhadap kualitas laba. 


\section{DAFTAR PUSTAKA}

Adriani, I. (2011). Pengaruh Investment Opportunity Set dan Mekanisme Corporate Governance terhadap Kualitas Laba dan Nilai Perusahaan. eprints.undip.ac.id2 diakses pada 22 November 2016

Dechow, P., Ge, W., Schrand, C. (2010). Understanding earnings quality: A Review of the Proxies, their deterninants and their consequences. Journal of Accounting and Economics 50, 344-401

Ghozali, I. (2013). Aplikasi Analisis Multivariate dengan Program IBM SPSS 21. Semarang: Badan Penerbit Universitas Diponegoro

Hashim, H. A., \& Devi, S. (2008). Board Characteristics, Ownership Structure and Earnings Quality: Malaysian Evidence. Journal of Accounting in Emerging Economies, 8, 97-123

Indrawati, N., \& Yulianti, L. (2010). Mekanisme Corporate Governance dan Kualitas Laba. Pekbis Jurnal, 2(2), 283-291

Jensen, M. C., \& Meckling, W. H. (1976). Theory of The Firm: Managerial Behavior, Agency Cost, and Ownership Structure. Journal of Financial Economics 3, 305-360

Kallapur, S., \& Trombley, M. A. (2001). The Investment Opportunity Set: Determinants, Consequences and Measurements. Managerial Finance, 27 (3)

Muid, D. (2009). Pengaruh Mekanisme Corporate Governance Terhadap Kualitas Laba. Fokus Ekonomi, 4 (2), 94-108

Myers, S. C. (1977). Determinant of Corporate Borrowing. Journal of Financial Economics, (5), 147-175.

Oktaviani, R. N. (2015). Pengaruh Good Corporate Governance terhadap Kualitas Laba dengan Manajemen Laba sebagai Variabel Intervening. Jurnal SOROI, 10 (1)

Paulus, C. (2012). Analisis Faktor-Faktor Yang Mempengaruhi Kualitas Laba. http://eprints.undip.ac.id/35697/ diakses pada tanggal 22 November 2016

Puteri, P. A. (2012). Analisis Pengaruh Investment Opportunity Set (Ios) dan Mekanisme Corporate Governance Terhadap Kualitas Laba Dan Nilai Perusahaan. Diponegoro Journal of Accounting, 1(2), 1-14

Rahmah, T. A. (2015). Analisis Pengaruh Mekanisme Corporate Governance Terhadap Kualitas Laba (Studi Kasus Pada Perusahaan Manufaktur Go Public Terdaftar di ISSI Periode 2011-2014). https://www.researchgate.net/publication/303525314 diakses pada tanggal 6 Maret 2017

Santoso, S. (2010). Statistik Parametrik. Jakarta: Elex Media Kopindo

Simamora, E. (2014). Pengaruh Investment Opportunity Set (IOS), Mekanisme Good Corporate Governance dan Reputasi KAP terhadap Kualitas Laba Perusahaan (Studi Empiris pada Perusahaan Property and Real Estate yang Terdaftar di Bursa Efek Indonesia 2010-2012). Jurnal Online Mahasiswa Bidang Ilmu Ekonomi Universitas Riau, 1 (2)

Suaryana, A. (2007). Pengaruh Komite Audit terhadap Kualitas Laba. Jurnal Ilmiah Akuntansi dan Bisnis, 2(1)

Tohir, R. (2013). Pengaruh Struktur Corporate Governance Pada Kualitas Laba dengan Intellectual Capital Disclosure Sebagai Variabel Intervening. Diponegoro Journal of Accounting, 2(4) 1-10

Undang-undang No. 40 Tahun 2007 tentang Perseroan Terbatas. 
Warianto, P. (2013). Pengaruh Ukuran Perusahaan, Struktur Modal, Likuiditas dan Investment Opportunity Set (IOS) Terhadap Kualitas Laba Pada Perusahaan Manufaktur yang Terdaftar di BEI. http:/e-journal.uajy.ac.id/4324/diakses pada tanggal 3 November 2016

Wulansari, Y. (2013). Pengaruh Investment Opportunity Set, Likuiditas dan Levergae Terhadap Kualitas Laba Pada Perusahaan Manufaktur yang Terdaftar di BEI. Jurnal Akuntansi Universitas Negeri Padang, 1 (2)

Yushita, A. N., Rahmawati, \& Triatmoko, H. (2013). Pengaruh Mekanisme Corporate Governance, Kualitas Auditor Eksternal, dan Likuiditas terhadap Kualitas Laba. Jurnal Economia, 9 (2)

Yusuf, M., \& Firdauz, E. (2005). Analisis Hubungan antara Berbagai Model Gabungan Proksi Investment Opportunity Set dan Real Growth dengan Menggunakan Pendekatan Confirmatory Factor Analysis. Jurnal Akuntansi dan Investasi, 6(1), 168-186 